\title{
UK's physical scientists are left disappointed by budget choices
}

[LONDON] Britain's physical scientists expressed both surprise and concern last week at the relatively large proportion of an

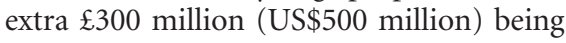
made available to research councils over the next three years that has been reserved for the life sciences.

In revealing how this extra money, first promised in July, is to be divided between research areas, the Department of Trade and Industry has announced that a key priority is to secure a "major expansion in molecular, biomolecular and biomedical research" (see Nature 395, 825; 1998).

In addition to a significant increase in funding for the Medical Research Council, the Engineering and Physical Sciences Research Council (EPSRC) has been told to spend $\mathfrak{E} 60$ million of its $\mathfrak{E} 86$ million extra income on research that underpins the work of the biomedical and environmental research councils.

The government is also to invest $£ 35$ million in DIAMOND, a planned synchrotron radiation source, in addition to $\mathfrak{E} 110$ million pledged by the Wellcome Trust. There will also be at least 57 new research fellowships, of which 12 are reserved for women, funded by the Royal Society and the Royal Academy of Engineering.

Research into climate change, ageing, information technology and communications will also be given funding priority, although precise amounts have yet to be spec-

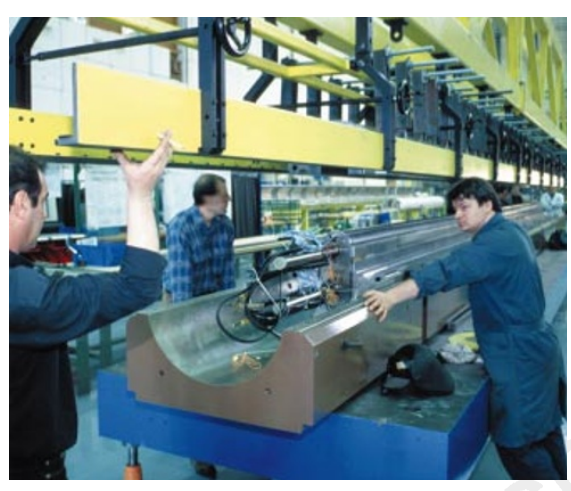

Secure: budget increase guarantees Britain's role in the construction of the Large Hadron Collider.

ified. But funding for particle physics and astronomy research will stay constant in real terms for the next three years.

Senior physicists say they had expected the biomedical and environmental sciences to do well in the distribution. But few expected them to walk away with almost 80 per cent of the extra money, leaving physical scientists and engineers working outside priority areas with $£ 46$ million.

Particle physicists and astronomers will receive $\mathfrak{£} 20$ million of this, an increase in real terms of just over half a per cent. This will be used for, among other things, supporting Britain's contribution to international projects such as the Large Hadron Collider at CERN the European Laboratory for Particle Physics in Geneva. The funds will also be used

\section{Dutch universities keep research control}

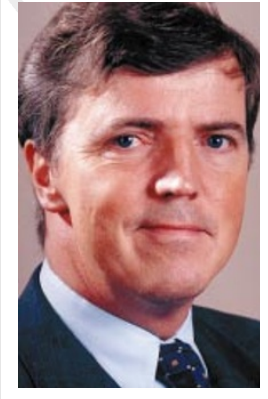

Hermans: Easing the universities' burden.
[AMSTERDAM] The planned transfer of a significant proportion of the research budget of Dutch universities to the national basic research organization, NWO, has been abandoned. The decision was announced by the new research minister Loek Hermans (left), who took office in August

following the re-election of a Liberal-Labour coalition government.

The transfer of Dfl 500 million (US\$267 million), about 20 per cent of the universities' research budget, had been planned last year by the previous government (see Nature 390, 9; 1997), which was also a coalition of Liberal and Labour parties. Unsurprisingly, the scheme had been championed by the NWO but opposed by universities, where most Dutch basic research is carried out.

Hermans, a professional politician with no research experience, told universities two weeks ago that he was abandoning the scheme because it would place too great a burden on them. They have recently been told that their general budget will be reduced in stages by Dfl 285 million over the next few years (see Nature 394, 405; 1998).

The NWO has not yet received formal notification of Hermans' decision. But Reinder van Duinen, NWO's president, describes the decision as "a shame" because he believes that the proportion of basic research money allocated through competitive grants is too low. To run a healthy dual funding system in the Netherlands, the amount of competitive grant money should be doubled, he says. for new fellowships for mid-career scientists, and a fund for new and innovative projects.

Other physical scientists whose work has no bearing on the environmental or biological sciences could fare worse. It is not yet known if their extra $\mathfrak{E} 26$ million represents a real-terms increase on present budgets.

Ken Pounds, head of the department of physics and astronomy at the University of Leicester, and a former chief executive of the Particle Physics and Astronomy Research Council (PPARC), admits that the overall situation has left many physicists unhappy.

"I personally think [keeping spending roughly level in real terms] is good news and reverses a 20-year trend," says Pounds. "But the situation is no better than marking time. It keeps [physics] alive."

Roger Cashmore, chairman of the department of physics at the University of Oxford, describes the distribution between the research councils as "a little peculiar", and thinks it is "somewhat unfortunate" that his own area of particle physics "did not do well at all".

Officials from PPARC and the EPSRC have greeted the extra funds as a long-awaited and much appreciated boost to their incomes.

The previous funding decline had led PPARC to close down the Royal Greenwich Observatory in Cambridge, a telescope building facility, and merge some of its work with the Royal Observatory in Edinburgh, creating a new Astronomy Technology Centre. The closure allows PPARC to invest $\mathfrak{£} 11$ million in its domestic programme.

PPARC and EPSRC welcome the chance to plan their expenditure over three years instead of just one. PPARC officials are also pleased by the decision of the government's Office of Science and Technology to hold an additional $\mathfrak{£} 30$ million to guarantee Britain’s contribution to existing international projects, such as the European Space Agency, in the event of currency fluctuations.

But privately their relief is said to be tempered with some concern. No one wants to complain, as that might seem ungrateful. But the feeling in the community, says one official, is: "When you give a starving man a slice of bread, he's really happy; but when he sees his chums eating cake, it hurts," he says. "That's how some of us feel right now."

Some officials are concerned that the imbalance in the distribution of the research funds may also be reflected in the distribution of an additional $\mathfrak{E} 600$ million fund for research infrastructure, half of which is being provided by the Wellcome Trust (see Nature 
395, 422; 1998).

The trust's status as a biomedical research charity means that at least $\mathfrak{£} 300$ million will be spent on biomedical research. But there are concerns that the overall proportion may be much greater. Indeed, questions have been asked as to whether the trust's involvement will skew the allocation of the overall fund towards the life sciences.

Asked to address this point by members of the House of Commons' science and technology committee last week, Mike Dexter, director of the trust, said that there were no strings attached to the overall funds. Indeed, Sainsbury, the science minister, said the trust's contribution to research infrastructure funding meant that, in total, the government was able to devote more funds to the physical sciences than it might otherwise have done.

Although there is disagreement over the proportion of research funds reserved for the life sciences, few doubted that life sciences would receive more than the physical sci-

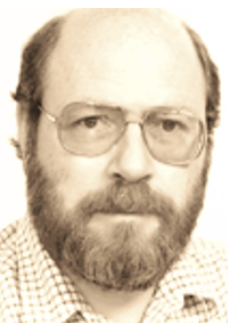
ences. Not only does it reflect a similar development in the United States, but it also ties in with the government's stated priorities to fund research that enhances its social and economic goals.

The government

Cashmore: division was 'a little peculiar'.

firmly takes the view that science is the bedrock of economic success. One of its stated goals, announced with the three-year allocations, is that the public-sector science base should contribute to a 50 per cent increase annually in the number of companies set up.

The government is aware that Britain is home to some of the world's leading pharmaceutical and biotechnology companies. Partly because of this, much of the investment in the life sciences will focus on exploiting the data to emerge from the Human Genome Project.

According to some, the economic potential of research, particularly in the life sciences, was a key factor on which Britain's finance ministry, the Treasury, agreed to release the extra funds in the first place.

The requirement that the EPSRC uses much of its new money to support the work in the life and environmental sciences is welcomed by one senior research council official as an opportunity for physical scientists and engineers to use their skills in other fields.

But he believes the government may be putting too much faith in the idea that highquality research is essential for commercial success. Japan's prosperous automobile and electronics companies succeeded not by having the world's best research, he says, but primarily by having higher productivity than Britain.

EhsanMasood

\section{Synchrotron report backs steps to efficient usage}

[MUNICH] National synchrotron facilities in Europe need to become more efficient, both technically and administratively, if they are to keep up with the increasing demand from life scientists, according to a report published by the European Science Foundation (ESF) two weeks ago.

Indeed, the report warns that unless this happens, an inadequate availability of synchrotron radiation facilities could hold back efforts to understand the function of novel proteins identified by genome sequencing programmes.

Synchrotron radiation has become an essential tool in protein crystallography. Structural information can be inferred from the patterns of X-ray scattering and absorption that result from impact with the molecules in a crystal, and synchrotron sources of $\mathrm{X}$-rays can be tuned to different wavelengths, allowing a wide range of proteins to be analysed.

The third-generation European Synchrotron Radiation Facility (ESRF) in Grenoble is particularly valued for the intensity of its X-rays, which allows bigger molecules to be analysed with less damage to the crystal. A further eight national facilities around Europe also provide dedicated beam lines for life scientists, with four more under construction and two in the proposal stage.

The ESF report endorses the need for the two proposed facilities, one near Barcelona in Spain and the other, named Soleil, in France. But it admits that any further proposals are unlikely to win financial support from national governments in the current economic climate.

Already the heavy demand means that scientists must often wait many months for beam time. This can cause problems for protein X-ray crystallography because of the instability of most protein crystals.

But the report says that such delays are often avoidable. Indeed, rather than recommending the construction of further synchrotron sources, it says existing ones should be made to function more efficiently, and makes five specific recommendations for increasing efficiency.

First, all beam lines should be equipped with CCD detectors - highly efficient X-ray detectors - to speed up the read-out of data. The ESRF has installed these on nearly all its beam lines. But despite their relatively low cost and their ability to increase throughput by about tenfold, national facilities have not always received money to make this upgrade.

Second, staffing of beam lines should be improved. Unlike physicists using synchrotron radiation, life scientists are often inex- perienced and need more help. But good beam-line operators are hard to find, and the report says that such positions should be made more attractive by allowing operators time to pursue their own research.

Third, and most importantly, the report says application procedures for beam-line time should be adjusted to meet the needs of the life sciences community. Many European scientists using synchrotron facilities in other countries are funded by the European Commission in Brussels. But the long procedure for peer reviewing commission research project applications introduces impractical delays for protein crystallographers.

The report therefore recommends a 'twin-track' system of time allocation: a block booking for highly qualified research groups, and a fast-track system, giving access to beam lines within a few days, for individual users with crystals that are difficult to obtain or store.

Block booking would mean a change in the peer-review system for individual projects, and scientists acknowledge that this is a sensitive issue. "There is obviously a need to be seen to be spending public money in an accountable way", says Keith Wilson, professor of chemistry at the University of York in the United Kingdom, and vice-chairman of the report's expert review panel.

Other protein crystallographers admit that synchrotron beam time is so precious, and the competition to publish so fierce, that researchers often run several projects in parallel, using beam time allocated for a particular peer-reviewed project for whichever of the projects has come to fruition at the appointed time. They also routinely send essentially the same applications to different facilities in Europe to increase the chances of securing time.

The ESF report's fourth suggestion is that synchrotron facilities consider providing services for collecting data and assessing the quality of crystals, to save expense and time bringing scientists to the site.

Finally, it suggests creating a committee of European synchrotron users and providers in the life sciences, administered by the ESF, and equivalent to the US organization Biosync. Such an umbrella organization could help coordinate and monitor the use of European facilities to identify problems and bottlenecks hampering efficient use.

Simon Phillips, an X-ray crystallographer from the UK's University of Leeds, agrees that the recommendations "make a lot of sense. Interesting crystals can be generated very suddenly, and it is frustrating to have to wait up to a year for beam time."

Alison Abbott 